[42] Lewis, B. (2004). The Crisis of Islam: Holy War and Unholy Terror. New York: Random House Publishing Group, 224.

[43] Europe after the terror attacks in Paris. Available at: https://www.facebook.com/priesimigracija/photos/a.1487413321558464.1073741828.1486261005007029/1507615206204942/?type=3\&theater Last accessed: 08.07 .2018

[44] Just a year ago, the world was shocked by the death of Alan Kurdi. Available at: https://www. facebook.com/pabegelis/ Last accessed: 10.08.2018

[45] Often a refugee seems to us like faceless nobody. Available at: https:/www.facebook.com/ pabegelis/ Last accessed: 08.07.2018

[46] When it comes to another race, nationality or religion the answer is not so easy. Available at: https://www.facebook.com/pabegelis/ Last accessed: 08.07.2018

[47] United Nations (2017). States Must Ensure Protection of World's Most Vulnerable Children, Mandate Holders Tell Third Committee, as Failure 'Could Not Be Condoned'. United Nations Meetings Coverage and Press Releases. Available at: https://www.un.org/press/en/2017/gashc4201.doc.htm Last accessed: 05.07.2018

[48] I do not feel safe since the arrival of refugees. Available at: https://www.facebook.com/pabegelis/ photos/a.156129754726345.1073741828.154086261597361/224365317902788/?type=3\&theater Last accessed: 19.08.2018

\title{
ACTUALIZATION OF METHODOLOGICAL SYSTEMS, SEPARATE FORMS AND METHODS OF NATIVE THEORY AND PRACTICE (END OF XIX - BEGINNING OF XX CENTURY) AS TO ORGANIZATION OF TEACHING FOREIGN LANGUAGES UNDER CONDITIONS OF FORMATION OF THE NEW UKRAINIAN SCHOOL
}

\author{
Nataliya Rybalko \\ Department of Elementary Education, which includes a section on Foreign Languages \\ Bogdan Khmelnitsky Melitopol State Pedagogical University \\ 20 Hetmanska str., Melitopol, Ukraine, 72300 \\ ribalkonatala@gmail.com
}

\begin{abstract}
The "foreign speaking competence" is an urgent task in the modern society. It is felt most acutely in countries of the post-Soviet space because of changing a paradigm of foreign language education, processes of integration of these countries in the world society. Organization of teaching foreign languages in the New Ukrainian school needs determining strategies and further perspectives as to the common work of pupils, parents and whole community on problems of the content and resource base for providing high-quality teaching taking into account the rich experience of teachers-practicians. The aim of the article is to use the historical experience for organizing teaching foreign languages for pupils of gymnasia. The brief analysis of substantial works of Ukrainian and foreign scientists as to the problem of organizing teaching foreign languages in tnative gymnasias at the end of XIX - beginning of XX century has been realized. Just this time there takes place a change of socio-economic conditions in the country that results in the fact that ancient foreign languages (Greek, Latin) lose their popularity. German, French and English occupy their place. It causes modernization of teaching methods and new organization of this process.

We have elaborated and introduced in the working practice of secondary educational institutions: the technology of a special seminar for improving the qualification of primary school teachers "Organization of teaching foreign languages for pupils: historical aspects and modern challenges" and technology of training exercises "Rozmovlyajko" for pupils of primary schools. We think that teaching foreign languages may serve as a means of reformation of the Ukrainian school and creation of a new productive and creative personality.
\end{abstract}

Keywords: New Ukrainian school, organization of teaching foreign languages, gymnasia, innovative methods. 


\section{Introduction}

Organization of teaching foreign languages in the modern Ukrainian school needs modernization. Actualization of the problem is connected with integrating the country in the world community and changing aims of teaching foreign languages in the modern Ukrainian society. For solving this problem, we find it expedient to actualize the historical-pedagogical experience and its combination with modern technologies.

The theoretical analysis of the experience of organizing teaching foreign languages for pupils of native gymnasias at the end of XIX - beginning of XX century favored understanding ideas as to organization of teaching foreign languages in modern conditions. This period was chosen not occasionally, because just that time national education formation had taken place, the civic movement had activated. A situation, formed at a turning point of the aforesaid centuries, was connected with radical changes in the society and, from our point of view, had much in common with modernity. We think that the potential of the obtained experience must be used under new conditions, when the New Ukrainian school begins to form for reviving its national tradition and intellectualization of the society.

According to the new State standard of primary education of the New Ukrainian school, a pupil must acquire different competences, one of which is "the ability to communicate in native (if different from the state one) and foreign languages" [1].

The problem of organizing teaching foreign languages in gymania education in works of Ukrainian teachers and linguists in the historical retrospective was studied in different times. There are such substantial studies, where the formation and development of gymnasia education in the second half of XIX - beginning of XX century [2]; development of classic education at Western Ukrainian territories (XIX - first half of XX century) [3]; theory and practice of organization of education of pupils in Kharkiv gymnasias of the second half of XIX - beginning of XX century [4]; and others are investigated on sources of the Eastern Ukrainian region. Discussion questions as to learning ancient languages in native gymnasia education of the second half of XIX - beginning of $\mathrm{XX}$ century are elucidated in monograph [5]; questions of theory and practice of teaching foreign languages as a component of the content of gymnasia education of the second half of XIX - beginning of XX century are presented in works [6]. The development dynamics of foreign speaking education in the period of the second half of XIX - beginning of XX century in the Kyiv education district is presented in scientific works [7].

The theme of education history in Galicia attracted certain foreign researchers. Especially, there must be noted the German scientist of the Ukrainian origin Sirka Ann, who made a comparative analysis of Ukrainian and Polish education in the whole and schools in Austria-Hungary at the end of XIX - beginning of XX century [8].

The Polish researcher of education history Józef Miąso, analyzing the educational system in Galicia, noted that a great influence on the development of Ukrainian education and culture was made by enlightening and scientific communities and also teacher organizations. A community «Proświta», created in 1868 published books, organized reading rooms, and also amateur choruses and theaters. Thus, at the end of XIX - beginning of XX century the favorable environment for intellectualization of the Ukrainian nation was created at the Western territories of Ukraine [9].

\section{Aim of research}

The analysis of legislative documents about education and scientific-methodical literature of native and foreign teachers on the studied theme; elaboration of the technology of a special seminar for improving the qualification of primary school teachers "Organization of teaching foreign languages for pupils: historical aspects and modern challenges" and the technology of training exercises "Rozmovlyajko" for primary school pupils and their introduction in the working practice of educational institutions.

\section{Methods}

The research results are based on the methods of: project work, brain storm, work in groups, method of questioning, interactive presentations, discussions, business games, role games, analysis of histories and situations, debate in a circle, synectics, focal objects. 
3. 1. Organization-methodical questions of introducing experience

3. 1. 1. The special seminar for improving the qualification of primary school teachers "Organization of teaching foreign languages for pupils: historical aspects and modern challenges".

An example of the practical use in the educational process of the New Ukrainian school for developing the foreign speaking competence is the special seminar for improving the qualification of primary school teachers "Organization of teaching foreign languages for pupils: historical aspects and modern challenges", elaborated and introduced in the working practice of educational institutions by us.

The special seminar was conducted on the base of the State higher education "Donbas state pedagogical university". The aim of the seminar was to actualize pedagogical ideas of famous teachers-scientists and to reveal the better practical experience of the work of teachers as to organization of teaching foreign languages.

The tasks of the seminar: deepening of knowledge of primary school teachers about the formation and development of teaching foreign languages and improvement of theoretical-methodical and organization aspects in teaching foreign languages in the New Ukrainian school taking into account possibilities, given by the modern reform.

The main methods of conducting the seminar: observation on the activity of primary school teachers, who teach a foreign language at schools as to the specificity of working with pupils in this direction; questionnaire of teachers; collection, analysis and generalization of information for further work.

The training to the seminar "Organization of teaching foreign languages for pupils: historical aspects and modern challenges" must be realized by project groups of 3-5 persons.

Different ideas, elaborated by teachers of the end of XIX - beginning of XX century as to organization of teaching foreign languages at native gymnasias are elucidated for the first group.

Especially, we planned different questions, among which:

1. Main pedagogical ideas of the end of XIX - beginning of XX century as to a teacher's role in organizing teaching foreign languages for pupils.

2. Views of scientists-linguists as to the program content of teaching foreign languages (ancient and modern languages).

3. Main forms, methods and ways of teaching foreign languages at the end of XIX - beginning of XX century.

4. Problems of organizing teaching foreign languages in the context of the social life of the studied period.

The second project group studies teaching foreign languages for pupils as a component of the educational process at school.

The questions that must be in the center of attention of this group are:

1. Main factors of the development of the organization system of teaching foreign languages for pupils at the end of XIX - beginning of XX century.

2. The development of the system of principles in teaching foreign languages at native gymnasias of the considered period.

3. General-didactic principles in teaching foreign languages as a base of successful studies of different languages. gymnasias.

4. The organization-methodical support of teaching foreign languages for pupils at native

The third project group must study and present the role of professional training of a teacher, who trains pupils in foreign languages at primary school according to the Conception of the New Ukrainian school.

Questions that may be considered are:

1. Professional training of a future primary school teacher for the organization of teaching foreign languages for pupils.

2. Peculiarities of training and improvement of the qualification of primary school teachers for the organization of teaching foreign languages according to the Conception of the New Ukrainian school. 
3. Professional training of a future primary school teacher to the organization of teaching foreign languages for pupils using new multimedia teaching means both at lessons and out-ofschool work.

4. Formation of a motivated primary school teacher as a guarantee of successful teaching of pupils.

The fourth project group must open the modern condition and development perspectives of ideas of main didactic principles of the organization of teaching foreign languages.

Especially, the following tasks were offered by us:

1. The use of the practical experience in the organization of teaching foreign languages for pupils in the work of the New Ukrainian school.

2. Development factors of teaching foreign languages for pupils at native gymnasias of the end of XIX - beginning of XX century.

3. Modern forms, methods and ways of the organization of teaching foreign languages at school.

4. Development perspectives of teaching foreign languages at working with pupils of the New Ukrainian school.

At conducting the seminar each project group must open an own vision of the problem, thoughts as to ideas, contained in analyzed sources, conduct the analysis of the problem condition of one of competences of communication in foreign languages, offer an own solution as to the development of such competence as a mediation in the multicultural society, and also the skill to find the mutual understanding in the multicultural environment, that modern normative sources deal with [10].

3. 2. Introduction of the historical experience in the learning and cognitive activity of pupils of the New Ukrainian school

The technology of training exercises "Rozmovlyajko" for primary school pupils. The technology of training exercises "Rozmovlyajko" for primary school pupils was introduced in the work of the Melitopol secondary school of 1 degree № 17 and may be used at lessons of foreign languages, in the work of clubs of foreign languages and also at out-of-school activities at weeks of foreign languages. Its novelty is in the combination of the historical experience and modern innovative technologies at teaching foreign languages. It takes into account modern realities of the child life: gamization, computerization, desire to be popular, to optimize own time and must be directed at forming a new person with soft skills: communicative and leader abilities, creativity, language skills, emotional intellect, critical thinking, time-management, solving of non-standard tasks, ability to work in a team and others alongside with concrete knowledge. The technology has the following structure:

Aim: to form a motivation as to communication in foreign languages in pupils, understanding of the own importance for solving problems, appeared in the communicative activity.

Tasks: to increase the pupils' interest in studying foreign languages by communication; to create visual materials that provide rationalization of the learning-upbringing process together with pupils.

The preparation to training exercises is realized by project groups of 3-5 persons, whose activity is organized by a teacher. Each group is offered to prepare a mini-presentation as to elucidating one of themes of everyday communication in foreign language.

The training course:

1. Announce of the theme and its aim.

The opening address of a teacher: "Children, today we'll try to talk in such a way that children in different countries do it. How children, for example, in the USA/in France/in Germany communicate between themselves?"

2. Preparatory stage. Activation of the vocabulary by the theme, introduction and discussion of ideas by pupils, creation of a plan (scenario) of a presentation, correction of mistakes. The work with a presentation.

3. Presentation of elaborated materials and communication situations by pupils of the groups. 
4. A discussion takes place after each presentation. Pupils in turn express own thoughts as to an elucidated situation in communication, there is also considered a possibility of involving other pupils in solving a problem that would result in mutual understanding between carriers of different languages.

Let's give examples of exercises that may be used at lessons or out-of-school activities.

Exercise "Follow me. My native city".

Aim: to widen possibilities for pupils' self-expression, to create conditions for foreign speaking communication with representatives of different countries.

Each group is offered to find/make a photo or draw one-two pictures - images of the native city - images of places that they like mostly, where they like to spend time, what they want to show their foreign friends; to form several sentences (comments) about these places and to talk about them in foreign language. It is possible to create a Viber group / to present most interesting posts on the site of a school / blog of a foreign language teacher and to involve other pupils in a dialog. It is also possible to conduct a battle of group presentations of the own city, where each group of participants talk foreign guests about famous places.

\section{Exercise "Move and talk"}

Aim: to widen pupils' knowledge about different activities of a child in foreign language.

Each group of pupils is offered to remember and to write on sheets of paper words that the notion "my activities" is associated with for them. Variants, offered by each group, are presented on the table. Then general results are analyzed. A teacher offers pupils to demonstrate child activities, in turn indicating each of them. Pupils all together demonstrate activities by gestures (to swim, to play tennis, to jump, to run, to drive a bicycle and so on), in such a way activating and memorizing words. For further analyzing, pupils may be offered to make a small video-interview with their group. At making it (10-15 minutes) pupils practice their skills to put questions and to construct questioning and declarative sentences, to present own results, to be responsible and active, to be able to work in a team, develop their creativity and emotional intellect. At realizing a teacher observes the work of the groups, corrects and directs pupils. After finishing the preparatory phase, a teacher "collects" videos, recorded on smartphones or tablet and demonstrates them all participants on a computer or smart-table. Children look at video-interviews, discuss and chose the best by voting.

Exercise "My recommendations/lifehacks".

Aim: to form the experience of communication in everyday themes, upbringing of independence and responsibility in pupils.

A task for each group is to make a list of products for a party, necessary things for a travel, school things for the new school years, wishes for the New year and others in foreign language. At making it, pupils must indicate, what, from their point of view, is most pleasant and important for them.

\section{Exercise "my video-blog"}

Aim: the development of a skill to express an own thought in foreign language certainly on a camera; the development of creative skills and ability to work in a team, to group the class collective.

A task for each group was to make a video (up to 2 minutes) by the chosen theme. For example, "What I'm doing for learning to communicate in foreign language?", "My day", “ The diary of weather", "My city/village", "My favorite food", "My favorite hero" and so on. A teacher with pupils chooses a theme, activates a vocabulary, grammar constructions. Pupils write a scenario in groups, a teacher checks up, corrects and explains mistakes. After that pupils make a video, present it and discuss own results.

\section{Results}

1. During the whole history of the multilingual society studying foreign language was an important practical task. Today the "foreign speaking competence" is an urgent practical task. It is felt most acutely in countries of the post-Soviet space because of changing aims of foreign language education, processes of integration of these countries in the world society. It activates the scientific 
and state interest in this direction. A trend among studies is the address to the historical heritage of linguoeducation.

Thus, the Russian researcher Zakharova K.O. underlines that "many teaching methods, used in the history of foreign language education, haven't lose their practical importance till today. Multiple directionalities of pupils' needs, differences of their individual development and level of mastering foreign language, different cognitive abilities, dictate a necessity of using the whole diversity of teaching methods. The analysis of methodical concepts of the past serves just this aim. The understanding of the past experience enriches the modern practice, favors the development of scientific thought" [11, p. 74].

The other Russian researcher L. V. Lukina accents the importance of combining the historical experience and modern technologies for the effective teaching foreign languages. "It is very important for a teacher of foreign languages at the modern stage to be able to combine new ways and technologies in teaching foreign languages with traditional ones" [12, p. 57]

A cause of renewing the interest to organizational forms of teaching foreign languages in the historical context is seen by the Russian researcher O. A. Kovaleva in the fact that in the period from the end of 1980 - beginning of 2000 such type of a secondary educational institution as a gymnasia, which distinctive feature is an expanded program of foreign languages, regenerated in the post-Soviet society on the new conceptual base [13, p. 3]. Thus, conclusions and recommendations, gained by participants of the special seminar "Organization of teaching foreign languages for pupils: historical aspects and modern challenges" must be used and introduced in the pedagogical practice of the New Ukrainian school. At discussing the results of the seminar, it was offered to conduct not only traditional learning-methodical or scientific-practical seminars, but also trainings, webinars, in the first turn, on-line to involve more number of participants.

2. The modern life created a necessity of searching for new methods and approaches to teaching foreign languages. Innovative technologies (use of information and communication technologies, project work, work with computer and multimedia programs, distant technologies, creation of presentations in the software environment Microsoft, Power Point, use of resources of the world network Internet, studying in acts) became an important component of modern teaching foreign languages, created the interactive environment. The experience and results of their use have a wide spectrum of works in the time or geographic space.

The famous German teachers Gilla Hoppenstedt and Beata Widlok state that modern tendencies in teaching foreign languages are the communicative approach and the shift of studying a first foreign language from the secondary school to the primary one, at that the first meeting with a foreign language takes place in a kindergarten $[14, \mathrm{p} .10]$. The special attention is paid by the researchers to CLIL method (Content and language integrated learning), noting advantages of its results, namely: "pupils acquire stable skills in mastering foreign language. The active competence favors their ability to communicate in natural situations. Learning by this method gives pupils self-confidence, in the first turn, to such of them, who have no successes at a traditional lesson of foreign language" [14, p. 12]. They also accent that the integral, situation learning "with all emotions and feelings", different types of activity, game, song, rhythm and dance favor mastering of a foreign language to the great extent" [14, p. 13].

The complex of exercises "Rozmovlyajko" is based on the activity approach that directs a person to choose, to assess, to program, to construct different types of activity, favoring self-development and self-realization.

The Romanian researcher Adina Sacara-Onita in her article "The most important methods of teaching foreign languages" demonstrates the historical ground of modern teaching methods and explains a cause of their evolution. The author indicates that the communicative method, developed of the pragmatic-functional method in 70-ies of XX century, put a pupil in a center of the educational process. A pupil becomes an active partner, cooperates with other pupils in pair and groups. A teacher plays a new role of an assistant in the learning process that motivates a pupil to studying foreign languages [15, p. 133]. The essence of this method is used in the complex of training exercises "Rozmovlyajko". 
"Despite all advantages of the communicative method of teaching foreign languages, there are also certain shortcoming that must be corrected at using it. It concerns a problem of studying the grammar material. The results of the analysis of several communicative textbooks demonstrated that the grammar is presented a bit "broken"". It is indicated by the Ukrainian researcher Korol S. V. in his article "communicative approach in teaching foreign languages" [16, p. 134].

We think that the use of the technology of training exercises "Rozmovlyajko" allowed to fix a positive dynamics in the pupils' interest to studying foreign languages, favored their understanding of the importance of communicating in foreign language, upbringing of the value attitude to studying and so on.

\section{Conclusion}

Among the most important directions in teaching foreign languages for pupils, there must be separated:

- Creation of pedagogical conditions for organizing and conducting projects, seminars, training programs, enriched with a modern content, new technologies, methods of teaching foreign languages and so on;

- Improvement of the level of partner cooperation between schools and public and state organizations, centers of studying foreign languages, where communication can directly take place;

- Enrichment of everyday communication practices in different foreign languages using possibilities of information-communication technologies;

- Formation of the ability to communication in foreign languages by pupils in group communicative interaction;

- Use of new forms, methods and ways of teaching foreign languages among pupils and their parents for raising the motivation to studying in them.

For organizing teaching foreign languages, it is necessary to elaborate innovatory ideas that must favor the effectiveness of studying foreign languages, so the quality of education. We think that the formation of language skills of a person within such aspects as reading, writing, speaking and auding may be an expecting result.

\section{References}

[1] Nova ukrainska shkola. 2018. Available at: https://mon.gov.ua/ua/tag/nova-ukrainska-shkola

[2] Fatalchuk, S. D. (2010). Stanovlennia ta rozvytok himnaziinoi osvity Skhidnoukrainskoho rehionu (druha polovyna XIX - pochatok XX stolittia). Sloviansk: Vydavnytstvo B. I. Matoryn, 206.

[3] Kurliak, I. Ye. (2000). Rozvytok klasychnoi osvity na zakhidnoukrainskykh zemliakh (XIX persha polovyna XX stolittia). Kyiv, 28.

[4] Paladieva, A. F., Brit, N. M. (2015). Rozvytok pedahohichnykh dyskusii shchodo navchannia starodavnikh mov u vitchyznianii himnaziinii osviti (druha polovyna XIX - pochatok XX stolittia). Uman: FOP Zhovtyi O. O., 213.

[5] Lutaieva, T. V. (1998). Teoriia i praktyka orhanizatsii osvity uchniv u himnaziiakh Kharkova druhoi pol. XIX - poch. XX st. Kharkiv, 18.

[6] Dolapchi, A. Yu. (2008). Teoriia i praktyka navchannia inozemnykh mov yak skladovoi zmistu himnazychnoi osvity druhoi polovyny XIX - pochatku XX st. Kharkiv.

[7] Khmelivska, S. I. (2013). Periodyzatsiia rozvytku inshomovnoi osvity v serednikh navchalnykh zakladakh Rosiiskoi imperii v XIX - na pochatku XX stolittia. Pedahohichnyi dyskurs, 15, 729-734.

[8] Sirka, A. (1980). The Nationality Question in Austrian Education: The Case of Ukrainians in Galicia 1867-1914. European University Studies: Series III, History and Allied Studies, vol. 124. Frankfurt/ Main, Bern, and Cirencester, Eng.: Peter D. Lang, VIII, 230.

[9] Miąso, J. (1991). Z dziejów szkolnictwa ukraińskiego w Galicji (1867-1914). Rozprawy z dziejów oświaty, 51-73.

[10] Rekomendatsii 2006/962/ESIEvropeiskoho Parlamentu ta Rady (ES). Pro osnovnikompetentsii dlia navchannia protiahom usoho zhyttia (2006). No. 994_975. 18.12.2006. Available at: http://zakon0.rada. gov.ua/laws/show/994_975 
[11] Zakharova, E. A. (2017). Metody obucheniya inostrannomu yaziku v istoricheskom kontekste i ikh znachimost' v sovremennoy praktike inoyazychnogo obrazovaniya. Nauka i shkola, 3, 174-183.

[12] Lukina, L. V. (2007). TSeli i metody obucheniya inostrannymyazykam v istoricheskom i lingvodidakticheskom kontekste. Nauchnyy vestnik Voronezhskogo gosudarstvennogo arkhitekturno-stroitel'nogo universiteta. Seriya «Lingvistika i mezhkul'turnaya kommunikatsiya», 2, 56-62.

[13] Kovaleva, E. A. (2013). Stanovlenie i razvitie inoyazychnogo obrazovaniya v otechestvennoy gimnazii XIX - nachala XX vv. Moscow, 22.

[14] Hoppenstedt, G., Frühes, W. B. (2011). Fremdsprachenlernen mit dem CLIL-Ansatz Einführung und Praxisbeispiele. Goethe-Institut. München, 22. Available at: https://www.goethe.de/resources/files/pdf96/2clil-fruehes-fremdsprachenlernen.pdf

[15] Sacara-Onita, A. (2014). Die Wichtigsten Methoden des Fremdsprachenunterrichts. Annals of Faculty of Economics, 1 (2), 131-134.

[16] Korol', S. V. (2012). Komunikativniy pidkhid u navchanni inozemnikhmov. Pedagogichniy diskurs, 11, 133-136.

\title{
THE UNIVERSITY DIGITAL LIBRARY AS A CENTER FOR INCREASING THE DIGITAL COMPETENCES OF STUDENTS
}

\author{
Tatiana Shopova \\ Department of Cultural Studies \\ South-West University "Neofit Rilski" \\ 66 Ivan Michailov str., Blagoevgrad, Bulgaria, 2700 \\ tansha@swu.bg
}

\begin{abstract}
This paper aims to outline the advantages of increasing the quality of education at the University by describing some important organizational approaches and methodological guidelines for the development of digital competences among students. The study focuses on the level of digital (library) competencies among students and their need to use scientific information sources in the University Library. A survey was conducted using the direct individual inquiry method through a pre-designed questionnaire comprising 20 questions. The statistical apparatus includes statistical methods - frequency, mean value and confidence level - $95 \%$. The survey results suggest that in today's digital society it is particularly important for the Library to become an information-communicative center for improving the students' skills by using the rich collection of information and digital resources and increasing the quality of education and training at the University. The presented study seeks to offer new approaches and ways to motivate students toward effective use of digital information and of new tools for working in the digital environment.
\end{abstract}

Keywords: digital literacy, university students, digital library, librarians, librarian guide, digital repository.

\section{Introduction}

The acquiring of skills to use the new tools for accessing knowledge and the broad development of digital literacy is increasingly becoming a condition for promoting the employability of every citizen in a world where digital technologies are beginning to determine people's way of life and thinking. It is no coincidence that in 2007 the European Commission has highlighted the need to consider the problem of digital literacy [1]. Focusing the efforts on the learning outcomes into the education process has shown the need to build universal skills and competencies that are crucial for individual development and competitiveness in the digital age. Among these new skills, special emphasis was placed on building critical thinking, initiative and teamwork that will prepare individuals for their careers. In this regard, the highlight was put on forming skills for management, interpretation, presentation, critical evaluation of information, capacity for its building or application in the digital environment [2]. The adopted by the European Commission strategy for creating a digital society and developing digital skills is a continuation of 